\title{
Targeting Fibroblast Growth Factor Receptor (FGFR) and Phosphoinositide 3-kinase (PI3K) Signaling Pathways in Medulloblastoma Cell Lines
}

\author{
STEFAN HOLZHAUSER ${ }^{1}$, MONIKA LUKOSEVICIUTE ${ }^{1}$, TEODORA ANDONOVA ${ }^{2}$, \\ RAMONA G. URSU ${ }^{3}$, TINA DALIANIS ${ }^{1}$, MALIN WICKSTRÖM $^{2 *}$ and OURANIA N. KOSTOPOULOU ${ }^{1 *}$ \\ ${ }^{1}$ Department of Oncology-Pathology, Karolinska Institutet, Stockholm, Sweden; \\ ${ }^{2}$ Department of Women's and Children's Health, Karolinska Institutet, Stockholm, Sweden; \\ ${ }^{3}$ Department of Microbiology, University of Medicine and Pharmacy, Grigore T. Popa, Iasi, Romania
}

\begin{abstract}
Background/Aim: Medulloblastoma (MB) accounts for $20 \%$ of pediatric malignant central nervous system tumors. Treatment strategies, including surgery, radiation therapy and/or chemotherapy, are effective, but recurrence and metastasis frequently occur. Therefore, novel therapies are required. Herein, the effects of fibroblast growth factor receptor (FGFR) and phosphoinositide 3 kinase (PI3K) inhibitors on MB cells lines were evaluated. Materials and Methods: MB cell lines (UW228-3, DAOY, Med8a, D425, D283) were tested for sensitivity to FGFR (AZD4547) and PI3K (BEZ235 and BYL719) inhibitors by viability, cytotoxicity, apoptosis, and proliferation assays. Results: Single treatments with FGFR and PI3K inhibitors decreased viability and proliferation in a dose-dependent pattern in most cell lines. Combinination of the two type of drugs, increased sensitivity, especially of the most resistant cell line UW228-3. Conclusion: Combination treatments with FGFR and PI3K inhibitors were superior to single treatments with FGFR and PI3K inhibitors, especially with BEZ235, for MB cell lines.
\end{abstract}

This article is freely accessible online.

*These Authors equally contributed to this work.

Correspondence to: Ourania Kostopoulou, $\mathrm{PhD}$, Department of Oncology-Pathology, Karolinska Institutet, Bioclinicum J6:20, Karolinska University Hospital, 17164 Stockholm, Sweden. Tel: +46 85172764, e-mail: ourania.kostopoulou@ki.se; Malin Wickström, $\mathrm{PhD}$, Department of Women's and Children's Health, Bioclinicum J5:30, Karolinska University Hospital, 17164 Stockholm, Sweden. Tel: +46 85172764, e-mail: malin.wickstrom@ki.se

Key Words: Childhood cancer, medulloblastoma, PI3K inhibitors, FGFR inhibitors.
Cancer is a leading cause of death for children and adolescents around the world and approximately 300,000 children aged 0 to 19 years old are diagnosed with cancer each year (1). Although leukaemia is the most common cancer in childhood ( $30 \%$ of paediatric malignancies), brain and central nervous system (CNS) tumors are the most frequent among the solid tumors (20\% of childhood cancers) (2). Medulloblastomas (MBs), which are the main focus of the current study, are among the most common malignant brain tumors, accounting for $16-25 \%$ of all CNS tumors in children, and usually arise in the cerebellum (3-6). According to recent advances in genomics, gene expression profiling, and epigenomics, MBs are divided into at least four subgroups: Wingles/Integrated (WNT), Sonic Hedgehog (SHH), Group 3 and Group 4 (7-9). The largest subgroups are: Group 4 and SHH-activated MB, which account for $\sim 35 \%$ and $30 \%$ of tumors respectively, and they both have intermediate prognosis. Group 3 tumors are found in $25 \%$ cases and have the worst prognosis, while WNT comprises $10 \%$ of MB tumors and has the best prognosis $(7,10,11)$.

The current treatment of MBs consists of removal of the tumor by surgery, radiation therapy (X-rays or protons) and chemotherapy (12). Despite this multipronged approach to therapy, approximately $30 \%$ of patients still die from the disease, and survivors suffer from severe long-term side effects, including neurological deficits, endocrine disorders, and secondary cancers (13). Therefore, novel combination therapies, ideally with fewer side effects, are needed. In this context, the present study focuses on the fibroblast growth factor receptor (FGFR) and its downstream phosphatidylinositol 3-kinase (PI3K) pathways, which both could be potential targets for future treatment strategies for MB.

FGFRs are a family of receptor tyrosine kinases expressed on the cell membrane, and are crucial during development, as well as in adult cells. Their dysregulation has been implicated in a wide variety of cancers, such as urothelial carcinoma, 
hepatocellular carcinoma, ovarian cancer and lung adenocarcinoma (14). Moreover, Bourdeaut et al. have reported two cases in which germline mutations in FGFRs (FGFR2 and FGFR3) and craniosynostosis were associated with MB (15). In addition, in a study investigating the transcriptomic changes in MB, FGFR3 was found among the genes associated with treatment failure in MB patients (16). Furthermore, a study on ependymomas and pilocytic astrocytomas showed increased expression of FGFR1 and FGFR3 in aggressive ependymomas (17). Early phase clinical trials have been conducted with FGFR3-directed targeted therapies for glioblastoma multiforme, transitional cell carcinoma, and multiple myeloma carrying mutated FGFR3 (Clinical Trials. gov Identifier: NCT01975701, NCT02278978, NCT02401542, NCT02052778) indicating the potential of such therapies for other cancers. Nevertheless, for childhood cancer, knowledge of FGFR protein family is still limited, and new therapeutic targets are urgently needed.

PI3K is frequently altered in cancer $(18,19)$ and has been studied in more detail in childhood cancer. Gene amplifications or mutations of the PIK3CA gene have been identified in numerous solid tumors, as well as in MB (2027). Previous studies on MBs have shown that PI3K inhibitors alone, or combined with chemotherapy could potentially be used for MB treatment $(13,28,29)$.

Notably, we have recently shown that FGFR and PI3K inhibitors, especially in combination, efficiently decrease viability and proliferaton of childhood neuroblastoma (NB) cell lines (30). Hence, more information on the sensitivity of MBs to FGFR and PI3K inhibitors could be of great importance. In the current study, we have therefore tested a number MB cell lines for their sensitivity to FGFR (AZD4547) and PI3K (BEZ235 and BYL719) inhibitors alone.

\section{Materials and Methods}

Tumor cell lines and culture conditions. The MB cell lines DAOY (Group SHH) and D283 (inbetween Group 3 and 4) were purchased from ATCC (LGC Standards, Middlesex, UK), while the D425 and Med8a (both Group 3), and UW228-3 (group SHH) MB cell lines were kindly provided by Prof. M. Nistér (Karolinska Institutet). According to the Cancer Depencency Map portal (https://depmap.org/portal/), none of the included cell lines had any FGFR3 mutations, while DAOY had an in-frame deletion in the PIK3R1 gene. Furthermore, it has been documented that D425 (31) and Med8a (32) have Myc amplifications as all cell lines in Group 3 (6). DAOY cells were cultured in minimum essential media (MEM) and UW228-3 in Dulbecco's modified Eagle medium:nutrient mixture F-12 (DMEM/F-12). D283 and Med8a were cultured in DMEM/F-12 with GlutaMAX, while D425 was cultured in 50\% Richer's improved MEM with zinc and 50\% DMEM. Cells were maintained in media supplemented with $10 \%$ fetal bovine serum (FBS), $1 \% \mathrm{~L}$-glutamine, $100 \mathrm{U} / \mathrm{ml}$ penicillin, and $100 \mu \mathrm{g} / \mathrm{ml}$ streptomycin at $37^{\circ} \mathrm{C}$ in a humidified incubator with $5 \% \mathrm{CO}_{2}$. All media and FBS were obtained from Gibco, Waltham, MA, USA.

Cell seeding and drug treatment. The two adherent cell lines, DAOY and UW228-3, were seeded in 96-well plates, at concentrations of
$2.5 \times 10^{3}$ and of $5 \times 10^{3}$ cells $/ 90 \mu 1$ medium/well, respectively, for the viability assay and $5 \times 10^{3}$ cells $/ 200 \mu \mathrm{m}$ medium/well for all other assays. The peripheral wells of the plates were filled with medium to avoid edge effects. The D425, D283 and Med8a cell lines, all growing in suspension, were seeded at a concentration of $10^{4}$ cells/90 $\mu \mathrm{l}$ medium/well for the viability assay, and $2 \times 10^{4}$ cells/200 $\mu \mathrm{l} /$ well for the proliferation, apoptosis, and cytotoxicity assays. Penicillin and streptomycin were excluded in the media in the different assays to avoid any interference with the drugs.

Dactolisib (BEZ235, NVP-BEZ235) and Alpelisib (BYL719), which were used as PI3K inhibitors, and AZD4547, used as FGFR inhibitor, were purchased from Selleckhem Chemicals (Munich, Germany). Stock solutions of the drugs were diluted in DMSO, and were furthrer diluted in PBS before use. The range of concentrations for BYL7 19 were $0.25-100 \mu \mathrm{M}$, for BEZ235, 0.25-5.0 $\mu \mathrm{M}$, and for AZD4547, 5.0-50 $\mu \mathrm{M}$. The inhibitors were added in the culture 24 $\mathrm{h}$ after cell seeding. Subsequently, the cells were incubated for 24 , 48,72 , or 96 h to investigate cell viability, cytotoxicity, apoptosis and proliferation. All the experiments were repeated at least three times. Standard deviation values were provided for the cell viability and proliferation data. For cytotoxicity and apoptosis assays only representative figures are presented, since the aim was to view whether cytotoxicity and/or apoptosis occurred.

WST-1 viability assay. Viability was measured using the WST-1 assay (Roche Diagnostics, Mannheim, Germany) following the protocol described previously in more detail (30).

Proliferation assay. For the proliferation assay, the cells were seeded in 96-well plates as described above. The plates were placed into the IncuCyte S3 Live ${ }^{\circledR}$ Cell Analysis System (Essen Bioscience, Welwyn Garden City, UK) for $24 \mathrm{~h}$ and were scanned every $2 \mathrm{~h}$. Twenty-four hours after cell seeding, the appropriate drugs or PBS (for control cells) were added. The incubation as well as cell scanning were continued for $72 \mathrm{~h}$. Cell proliferation was determined by image analysis, measuring the confluence of the cells.

Cytotoxicity and apoptosis assay. The cytotoxicity and apoptosis assays were simultaneously performed using the Incucyte ${ }^{\mathrm{TM}}$ Cytotox Red Reagent (Essen Bioscience) and the IncuCyte Caspase-3/7 Green Apoptosis Assay Reagent (Essen Bioscience), respectively. The red fluorescent reagent enters the damaged plasma membrane and binds to DNA. Briefly, cells were seeded in 96-well plate as described above and were incubated for $24 \mathrm{~h}$ in the IncuCyte S3 Live ${ }^{\circledR}$ Cell Analysis System (Essen Bioscience). Cell images were captured every $2 \mathrm{~h}$. For the adherent cells, the medium was discarded and replaced with fresh containing the IncuCyte Cytotox Red reagent at a final concentration of $250 \mathrm{nM}$ and the IncuCyte Caspase-3/7 Green Apoptosis reagent at a ratio of $1: 1,000$. For the suspension cells, half of the medium was carefully replaced with fresh containing the two reagents. Subsequently, the PI3K and FGFR inhibitors were added, either alone or in combination, and PBS was added as a negative control; incubation and scanning were continued for $48 \mathrm{~h}$. Dead cells were quantified by counting the red nuclei, while apoptotic cells were automatically visualized and quantified by measuring green fluorescence using the IncuCyte analysis software .

Statistical analysis. To determine the effects of single or combination treatments, a multiple $t$-test accompanied by a correction for multiple comparison of the means conferring to the 

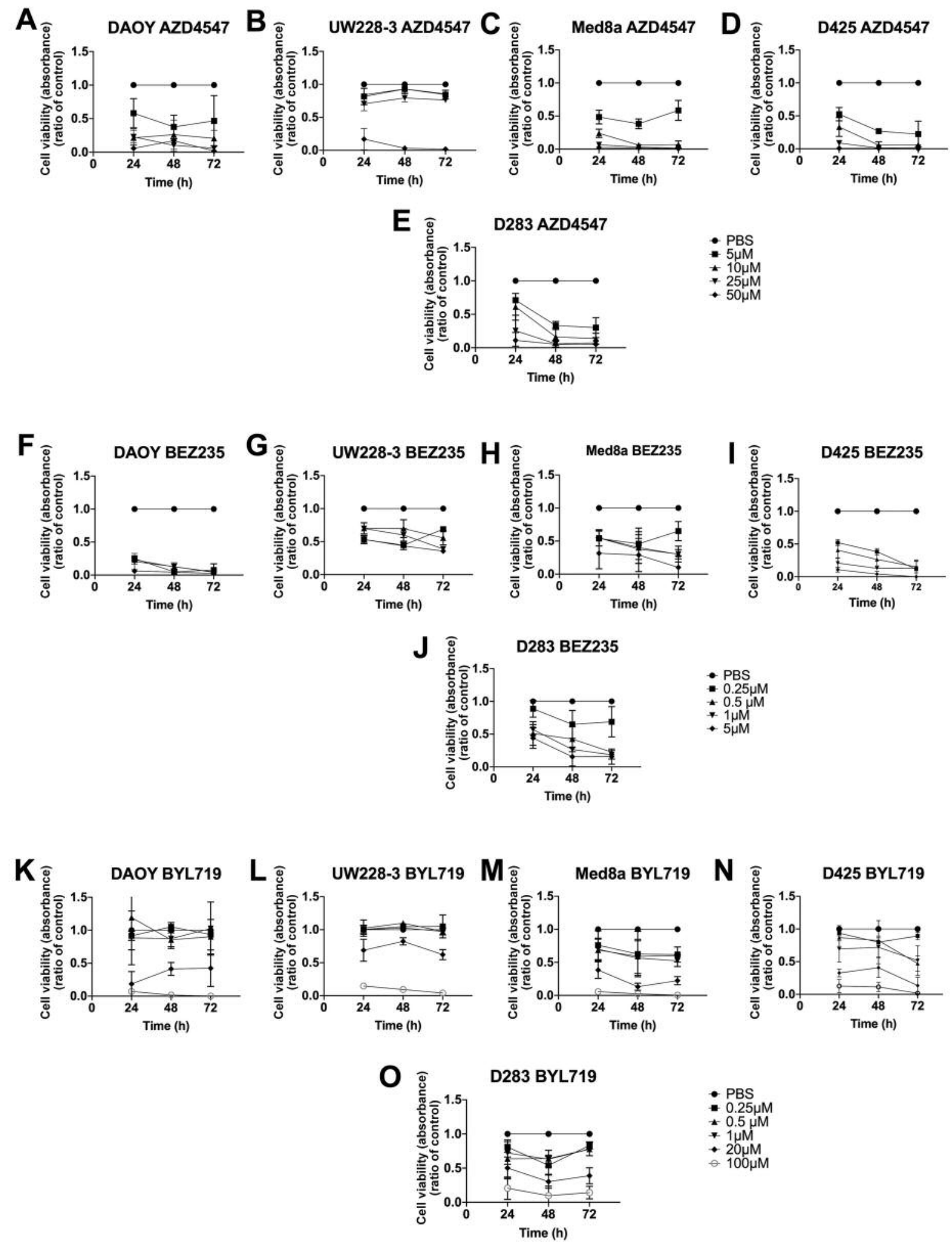

Figure 1. WST-1 viability assays after single treatment of FGFR and PI3K inhibitors on five MB cell lines. Viability analysis measured as absorbance, after treatment for 24, 48 and $72 \mathrm{~h}$ with the FGFR inhibitor AZD4547 (A-E); and the PI3K inhibitors BEZ235 (F-J) and BYL719 $(K-O)$, on DAOY, UW228-3, Med8a, D425 and D283, respectively. The graphs represent mean values \pm standard deviation (SD) from three experimental runs per cell line. 
Holm-Sidak method was performed as previously described in detail (30). To evaluate the combined effects of the drugs, the effect-based approach 'Highest Single Agent' and the dose-effect-based approach 'median-effect method' (based on Loewe Additivity) were used (33). A combination index (CI) was calculated as previously described; a CI of $<1$ was considered a positive and a CI of $>1$ a negative combinational effect (30). Additionally, the combined effects were analyzed using the median-effect method of Chou (Chou-Talalay method) as previoiusly described $(30,34)$. In short, dose-response curves were fitted to a linear model using the median-effect equation, leading to calculation of a median-effect value $\mathrm{D}$ (equivalent to $\mathrm{IC}_{50}$ ) and slope, also described in detail previously (30). Goodness-of-fit was assessed with the linear correlation coefficient, $r$; and an $r>0.85$ was required for a successful analysis. The degree of drug interaction was ranked using the $\mathrm{CI}$ for mutually exclusive drugs, with $\mathrm{CI}<0.70$ defined as synergy, $\mathrm{CI}<1.45$ as antagonism, and values in between as additive effects. One-way ANOVA with the Bonferroni post-hoc test was used to examine differences in means between the single two drugs and the combination treatment, $p<0.05$ was considered significant.

\section{Results}

Single treatments with FGFR and PI3K inhibitors decreased viability of MB cell lines DAOY, UW228-3, Med8a, D425, and D283 in a dose dependent manner. WST-1 viability assays were performed 24,48 , and $72 \mathrm{~h}$ after the treatment of DAOY, UW228-3, Med8a, D425, and D283 cell lines with FGFR and PI3K inhibitors alone. All drugs exerted dose-dependent effects on viability; however, the MB lines differed in sensitivity. Viability results are described in detail below; data including are shown in Figure 1, and compiled information is presented in Table I.

AZD4547. All MB cell lines exhibited a $\geq 50 \%$ decrease in viability after treatment with $50 \mu \mathrm{M}$ AZD4547 at 24, 48 and 72 $\mathrm{h}$; the decreases in viability for all cell lines were all significant compared to the PBS-treated controls (at least $p<0.001$; Figure 1A-E). Likewise, all cell lines except UW228-3, exhibited a $\geq 50 \%$ decrease in viability after treatment with $25 \mu \mathrm{M}$ AZD4547 at 24, 48, and $72 \mathrm{~h}$, and had significant decreases compared to the PBS-treated controls (at least $p<0.05$; Figure 1A-E). This was also the case for DAOY, Med8a, and D425 cells after treatment with $10 \mu \mathrm{M}$ AZD4547 at all time points, and for D283 cells at 48 and $72 \mathrm{~h}$ as compared to the PBStreated controls (at least $p<0.05$; Figure 1A-E).

BEZ235. Treatment with $5 \mu \mathrm{M}$ BEZ235 induced a $\geq 50 \%$ decrease in cell viability in all MB cell lines at all time points, except for UW228-3, in which a $\geq 50 \%$ decrease was induced 48 and $72 \mathrm{~h}$ after treatment; the decreases were all significant compared to the PBS-treated controls (at least $p<0.05$; Figure 1F-J). All cell lines, except UW228-3, also showed a $\geq 50 \%$ decrease in viability, after treatment with 0.5-1 $\mu \mathrm{M}$ BEZ235 after 48 and $72 \mathrm{~h}$ and the decreases were significant compared to the PBS-treated controls (at least $p<0.05$ ) (Figure 1F). This was also the case for DAOY and D425 cells treated with $0.25 \mu \mathrm{M}$ BEZ235 at all time points (at least $p<0.0001$; Figure $1 \mathrm{~F}$ and I).

BYL719. BYL719 was relatively less potent than BEZ235 at the concentrations used; however, BYL719 at $100 \mu \mathrm{M}$ induced a $\geq 50 \%$ decrease in viability as well as significant decreases at all time points in all MB cell lines, compared to the PBStreated controls (at least $p<0.01$; Figure $1 \mathrm{~K}-\mathrm{O}$ ). Treatment with $20 \mu \mathrm{M}$ BYL719 also resulted in $\geq 50 \%$ decrease of viability in all cell lines, except UW228-3; specifically, it induced significant decreases in DAOY, Med8a, and D425 cells at all time points, while in D283 cells only at 48 and $72 \mathrm{~h}$, compared to the PBS-treated controls (at least $p<0.05$; Figure $1 \mathrm{~K}-\mathrm{O}$ ).

$I C_{50}$ values from effect-concentration curves for BEZ235, $B Y L 719$ and AZD4547. To better evaluate the sensitivity of the different cell lines, $\mathrm{IC}_{50}$ values for all cell lines were calculated and are presented in Table $\mathrm{I}$. The mean $\log \mathrm{IC}_{50}$ value for BEZ235 was significanly lower than the mean $\log \mathrm{IC}_{50}$ values of both BYL719 and AZD4547, for all the tested cell lines (BYL719 vs. AZD4547 $24 \mathrm{~h} p=0.0051,48 \mathrm{~h} p<0.001$ and 72 $\mathrm{h} p=0.0015$; BEZ235 vs. BYL719 $24 \mathrm{~h} p=0.016,48 \mathrm{~h} p=0.024$, and $72 \mathrm{~h} p=0.041$ ). The data also indicated that D425 was the most sensitive cell line and UW228-3 was the most resistant cell line to treatment with AZD4547, with the other cell lines had intermediate sensitivity. For BEZ235 and BYL719, the $\mathrm{IC}_{50}$ values indicated that UW228-3 cell line was the least sensitive, with all other cell lines having more intermediate sensitivities and BEZ235 being more efficient than BYL719 (Table I). To limit the number of cell lines used, assays on cytoxocity, apoptosis and proliferation were therefore not further pursued on D283 cells.

Cytotoxicity analysis on the MB cell lines DAOY, UW228-3, Med8a, and D425, following single treatment with FGFR and PI3K inhibitors indicated that only AZD4547 induced considerable cytotoxicity. The cytotoxic effect of treatment with AZD4547 (FGFR inhibitor), BEZ235, and BYL719 (both PI3K inhibitors) on the MB cell lines DAOY, UW228-3, Med8a, and D425 was evaluated by the IncuCyte Red Cytotoxicity reagent assay. Treatment with $25 \mu \mathrm{M}$ AZD4547 induced cell cytotoxicity on DAOY, Med8a and D425, but had no cytotxic effect on UW228-3 cells (Figure 2A-D). Some cytotoxicity was also noted after treatment with $10 \mu \mathrm{M}$ AZD4547 in Med8a and D425 cells (Figure 2C and D). BEZ235 and BYL719 did not induce marked cytotoxicity on any of the cell lines in comparison to the PBS-treated controls, or to AZD4547-treated cells (Figure 2E-H and I-L, respectively).

Apoptosis analysis on MB cell lines DAOY, UW228-3, Med8a, and D425, following single treatment with FGFR or PI3K 
Table I. WST 1 viability analysis following treatment with the fibroblast growth factor receptor (FGFR) inhibitor, AZD4547, and the phosphoinositide 3-kinase (PI3K) inhibitors, BEZ235 and BYL719 for 24,48 , and $72 \mathrm{~h}$.

\begin{tabular}{lccccc}
\hline & & & \multicolumn{3}{c}{$\mathrm{IC}_{50}(\mu \mathrm{M})$} \\
\cline { 3 - 6 } Cell lines & & & & \\
\cline { 3 - 5 } D283 & FGFR & AZD4547 & 11.8 & 2.77 & 2.23 \\
& PI3K & BEZ235 & 2.09 & 0.404 & 0.336 \\
& & BYL719 & 7.90 & 1.49 & 6.79 \\
D425 & & & & & \\
& FGFR & AZD4547 & 5.61 & 3.38 & 2.74 \\
& PI3K & BEZ235 & 0.279 & $<0.250^{\mathrm{a}}$ & $<0.250^{\mathrm{a}}$ \\
& & BYL719 & 5.86 & 6.18 & 0.961 \\
DAOY & & & & & \\
& FGFR & AZD4547 & 5.46 & 2.18 & 4.61 \\
& PI3K & BEZ235 & $<0.250^{\mathrm{a}}$ & $<0.250^{\mathrm{a}}$ & $<0.250^{\mathrm{a}}$ \\
& & BYL719 & 6.97 & 10.2 & 18.6 \\
Med8a & & & & & \\
& FGFR & AZD4547 & 4.81 & 4.30 & 5.42 \\
& PI3K & BEZ235 & 0.763 & $<0.250^{\mathrm{a}}$ & 0.351 \\
& & BYL719 & 3.62 & 0.960 & 0.974 \\
UW228-3 & FGFR & AZD4547 & 30.5 & 30.5 & 29.4 \\
& PI3K & BEZ235 & $>5.00$ & 3.86 & 0.938 \\
& & BYL719 & 32.9 & 38.3 & 24.9 \\
\hline
\end{tabular}

$\mathrm{The} \mathrm{IC}_{50}$ (inhibitory concentration 50\%) for each cell line for each drug was determined from log concentrations-effect curves in GraphPad Prism using non-linear regression analysis. FGFR, Fibroblast growth factor receptor; PI3K, phosphatidylinositol 3-kinase. ${ }^{a}$ The $\mathrm{IC}_{50}$ value could not be determined; lowest/highest tested concentration closest to the $\mathrm{IC}_{50}$ is reported. The mean $\log \mathrm{IC}_{50}$ value for BEZ235 was significantly lower than for the mean $\log \mathrm{IC}_{50}$ values for both BYL719 and AZD4547 in all the investigated cell lines at all three time points (one-way ANOVA with Bonferroni post test; BYL719 vs. AZD4547 $24 \mathrm{~h} p=0.0051,48 \mathrm{~h}$ $p<0.001$ and $72 \mathrm{~h} p=0.0015$, BEZ235 vs. BYL719 $24 \mathrm{~h} p=0.016,48 \mathrm{~h}$ $p=0.024$, and $72 \mathrm{~h} p=0.041$ ). The mean $\log \mathrm{IC}_{50}$ between AZD4547 and BYL719 did not differ significantly at any time point.

inhibitors indicated that only AZD4547 induced apoptosis. Treatment with the FGFR inhibitor AZD4547 at $25 \mu \mathrm{M}$, but not at lower concentrations, induced apoptosis in DAOY, Med8a, and D425 cell lines, and not in UW228-3 (Figure 3AD). Treatments with lower AZD4547 concentrations as well as with BEZ235 and BYL719 did not induce prominent cytotoxicicty (Figure 3).

Proliferation assays on $M B$ cell lines DAOY, UW228-3, Med8a, and D425 indicated sensitivity to high doses of single treatments with FGFR inhibitor AZD4547 and PI3K inhibitors BEZ235 and BYL719. All the tested MB cell lines showed a complete or near-complete inhibition of proliferation after treatment with $25 \mu \mathrm{M}$ AZD4547 (DAOY: $p=0.004$, UW228-3: $p=0.0001$, Med8a: $p=0.023$, D425: $p=0.05$; all after $72 \mathrm{~h}$ ) (Figure 4A-D). Treatment with $10 \mu \mathrm{M}$
AZD4547, also induced cell growth inhibition, however, only in Med8a ( $p=0.029$, at 72h) (Figure 4C).

Treatment with $5 \mu \mathrm{M}$ BEZ235 showed a tendency for growth inhibition in all MB cell lines with statistical significance only in the D425 cell line ( $p=0.001$, at $72 \mathrm{~h})$ (Figure 4E-H). D425 cell growth was also inhibited significantly after treatment with $1 \mu \mathrm{M}$ BEZ235 ( $p=0.0002$, at $72 \mathrm{~h}$ ), while 1 and $0.5 \mu \mathrm{M}$ BEZ235 had the same effect only in D425 cells ( $p=0.001$, at $72 \mathrm{~h}$ ) (Figure 4E-H). Finally, regarding treatment with BYL719, cell growth of all the tested MB cell lines was inhibited after treatment with 100 $\mu \mathrm{M}$ of the drug (DAOY: $p=0.006$, UW228-3: $p=0.003$, Med8a: $p=0.05$, D425: $p=0.04$; all at 72h) (Figure 4I-J).

Treatment of with AZD4547 and BEZ235 or BYL719 combined enhanced inhibition of viability in most of the $M B$ cell lines. All the tested AZD4547 and BEZ235 combinations induced $\mathrm{a} \geq 50 \%$ decrease in viability of DAOY and D425 cells at all time points as well as significant decreases when compared to PBS-treated controls (at least $p<0.01$; Figure $5 \mathrm{~A}$ and D). A $\geq 50 \%$ decrease in viability and significant decreases in viability were also noted in UW228-3, Med8a and D283, 48 and $72 \mathrm{~h}$ after treatment with almost all AZD4547 and BEZ235 combinations, compared to PBS-treated controls (at least $p<0.05$; Figure 5B, C and E).

AZD4547 and BYL719 combinations also induced higher viability decreases compared to single treatments, but were here less efficient than AZD4547 and BEZ235. Combination treatments with $25 \mu \mathrm{M}$ AZD4547 and 1.0 $\mu \mathrm{M}$ BYL719, as well as with $10 \mu \mathrm{M}$ AZD4547 and $20 \mu \mathrm{M}$ BYL719 induced $\geq 50 \%$ decrease in DAOY, Med8a, D425 and D283 cells, compared to PBS-treated controls, at all time points (at least $p<0.05$; Figure 5F-J). Likewise, for UW228-3 cells, a $\geq 50 \%$ decrease in viability and significant decreases compared to PBS controls were observed for the $25 \mu \mathrm{M}$ AZD4547 and 1.0 $\mu \mathrm{M}$ BYL719 combination, at all time points, and for the $10 \mu \mathrm{M}$ AZD4547 and $20 \mu \mathrm{M}$ BYL719 combination at 48 and $72 \mathrm{~h}$ (at least $p<0.0001$; Figure 5G).

To further evaluate possible synergism, additive effects or antagonism between the two drug combinations, two different methods were used: the effect-based Highest Single Agent approach and dose-effect-based median-effect principle. CIs from both approaches assessing combinational effects at $24 \mathrm{~h}$ are displayed in Figure 6. The majority of the tested combinations with AZD4547 were rated as positive by the Highest Single Agent approach (combined with BYL719: 18/25; combined with BEZ235 19/25 tested combinations, Figure 6A and B). Similarly, according to the median-effect principle, the majority of combinations with AZD4547 had an either additive or synergistic combinational effect (combined with BYL719: 18/25; combined with BEZ235 13/15 tested combinations could be evaluated having additive/synergistic effects) (Figure 6C and D). Furthermore, in the resistant cell line UW228-3, a significantly improved effect of the 

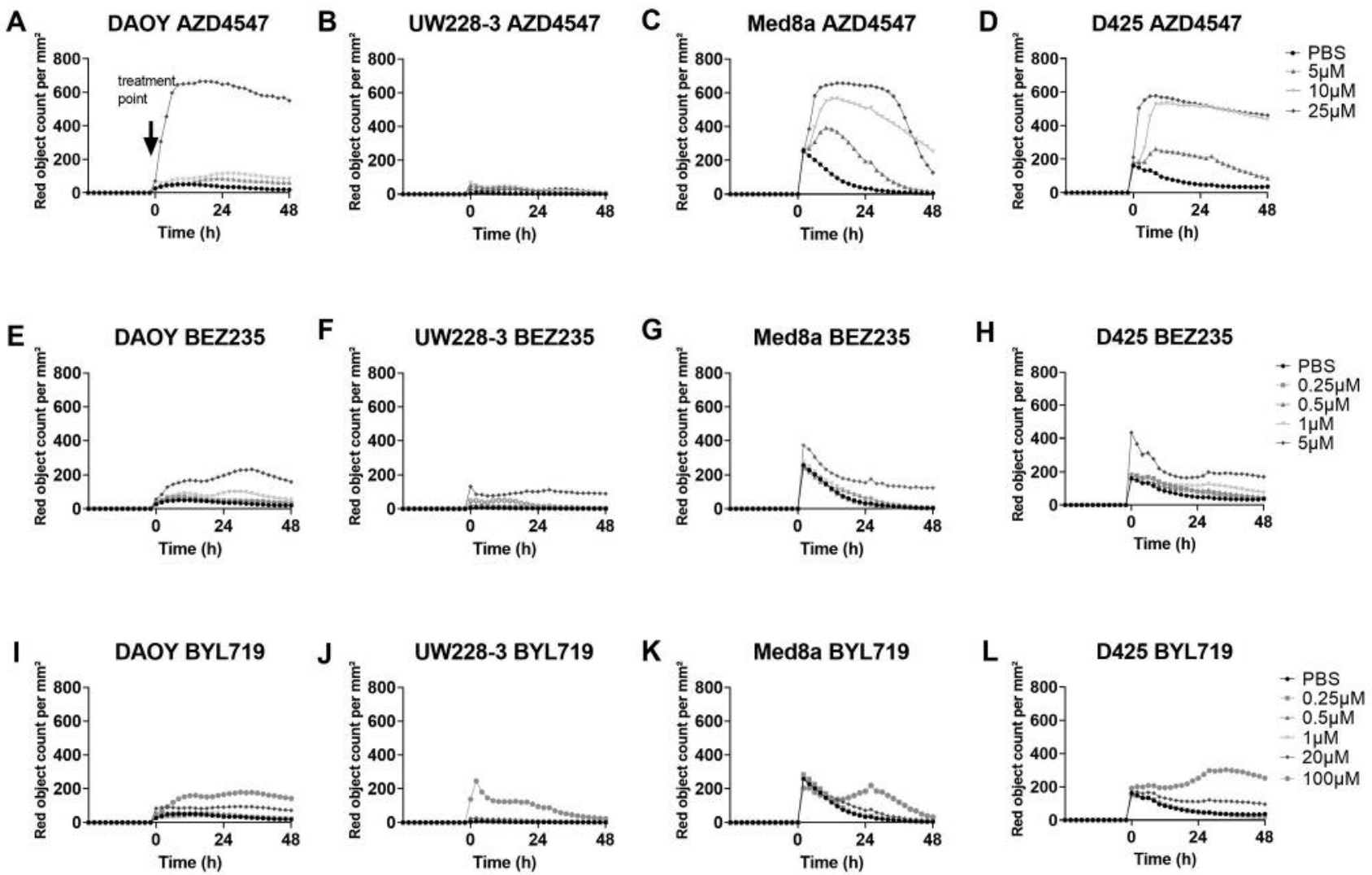

Figure 2. Cytotoxicity analysis after single treatments with FGFR and PI3K inhibitors using the IncuCyte Red Cytotoxicity Assay on the MB cell lines DAOY, UW228-3, Med8a, and D425. Twenty-four hours after seeding, at $0 \mathrm{~h}$ time point, the indicated cell lines were treated with drugs and the assays were performed up to 48 h after treatment, with FGFR inhibitor AZD4547 (A-D); with PI3K inhibitor BEZ235 (E-H); and BYL719 (I$L)$. The graphs represent one out of three typical experiments.

combinations of AZD4547 and BEZ235 compared to single drug treatment was observed after $48 \mathrm{~h}$ in 4 out of 5 tested combinations (AZD4547 $5 \mu \mathrm{M}$ and BEZ235 $0.25 \mu \mathrm{M} v s$. AZD4547 $5 \mu \mathrm{M} p<0.0001$ and $v s$. BEZ235 $0.25 \mu \mathrm{M} p=0.094$; AZD4547 $10 \mu \mathrm{M}$ and BEZ235 $0.5 \mu \mathrm{M} v s$. AZD4547 $10 \mu \mathrm{M}$ $p=0.0004$ and $v s$. BEZ235 $0.5 \mu \mathrm{M} p=0.0052 ;$ AZD4547 10 $\mu \mathrm{M}$ and BEZ235 $1 \mu \mathrm{M} v s$. AZD4547 $10 \mu \mathrm{M} p<0.0001$ and vs. BEZ235 $1 \mu \mathrm{M} p=0.0047$; AZD4547 $25 \mu \mathrm{M}$ and BEZ235 $1 \mu \mathrm{M} v s$. AZD4547 $25 \mu \mathrm{M} p=0.0001$ and $v s$. BEZ235 $1 \mu \mathrm{M}$ $p=0.0017$; AZD4547 $5 \mu \mathrm{M}$ and BEZ235 $5 \mu \mathrm{M} v s$. AZD4547 $5 \mu \mathrm{M} p<0.0001$ and $v s$. BEZ235 $5 \mu \mathrm{M} p=0.016$; Figure 6E-I).

Combination treatment of MB cell lines with FGFR and PI3K inhibitors did not enhance cytotoxicity compared to single treatments with AZD4547. The combined use of $25 \mu \mathrm{M}$ AZD4547 and $1 \mu \mathrm{M}$ BEZ235 as well as $25 \mu \mathrm{M}$ AZD4547 and $1 \mu \mathrm{M}$ BYL719 resulted in a similar cytotoxicity, as the use of $25 \mu \mathrm{M}$ AZD4547 alone in DAOY, Med8a and D425 cells, while no increase was observed in UW228-3 cells (Figure 7).
Treatment of DAOY, UW228-3, Med8a, and D425 cell lines with FGFR and PI3K inhibitors in combination did not alter apoptosis compared to single treatment with AZD4547. Combined treatment with $25 \mu \mathrm{M}$ AZD4547 ans $1 \mu \mathrm{M}$ BEZ235, or $25 \mu \mathrm{M}$ AZD4547 and $1 \mu \mathrm{M}$ BYL719 resulted in an apoptosis pattern similar to that induced by $25 \mu \mathrm{M}$ AZD4547 alone for DAOY, Med8a and D425, with no increase observed for UW228-3 (Figure 8).

Treatment of DAOY, UW228-3, Med8a, and D425 cell lines with FGFR and PI3K inhibitors combined showed enhanced inhibition of proliferation as compared to single treatments. The combination of $25 \mu \mathrm{M}$ AZD4547 and $1.0 \mu \mathrm{M}$ BEZ235 inhibited proliferation of the four tested MB cell lines (DAOY: $p=0.006$, UW228-3: $p=0.0001$, Med8a: $p=0.037, \mathrm{D} 425$ : $p=0.019$ ) (Figure 9A-D). In addition, the combinations $10 \mu \mathrm{M}$ AZD4547 and $0.5 \mu \mathrm{M}$ BEZ235, as well as $10 \mu \mathrm{M}$ AZD4547 and $0.25 \mu \mathrm{M}$ BEZ235 showed a tendency to inhibit proliferation (Figure 9A-D). 

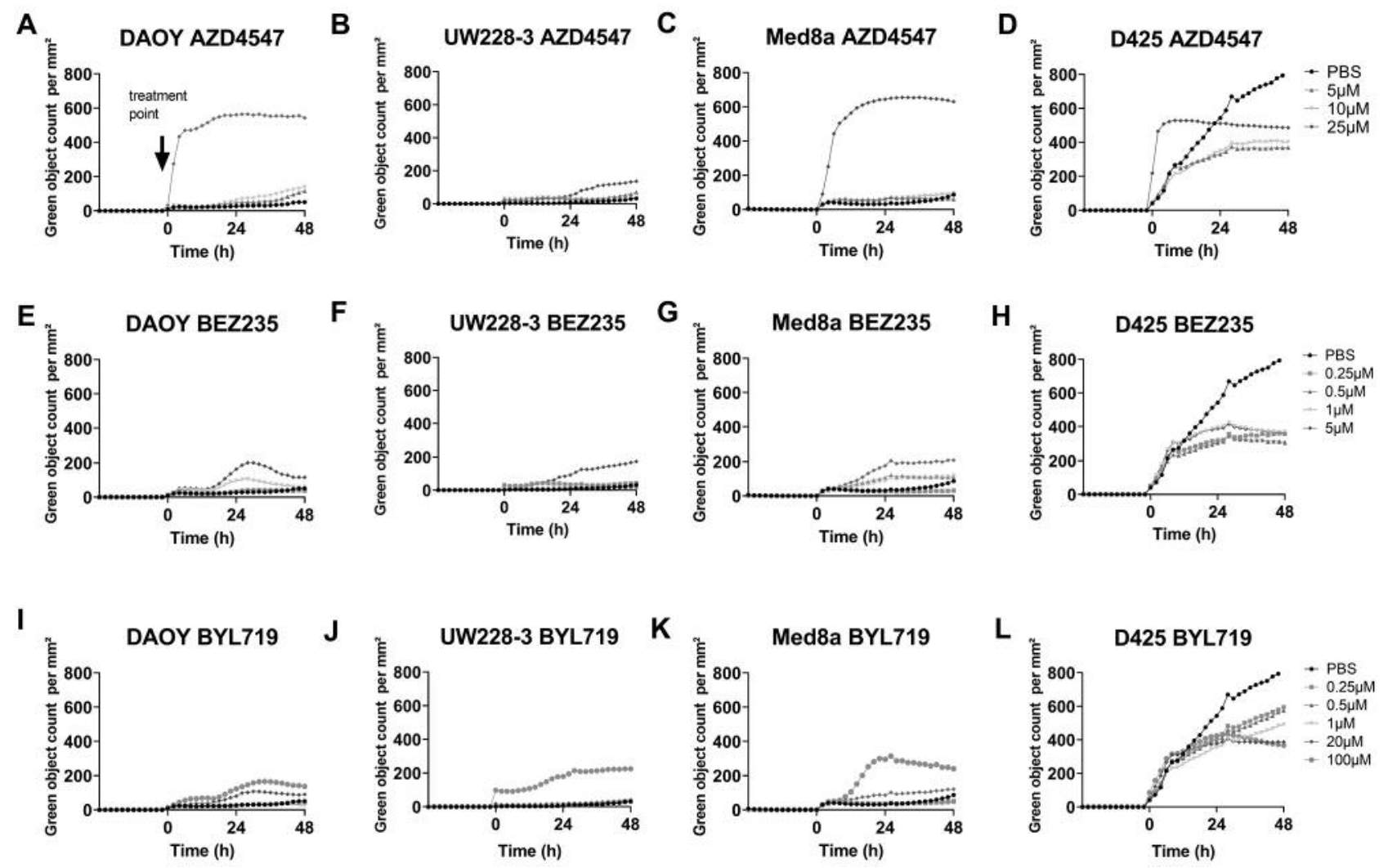

Figure 3. Caspase-3/7 Green Apoptosis assay after single treatments with FGFR and PI3K inhibitors on cell lines DAOY, UW228-3, Med8a, and D425 using the IncuCyte S3 Live ${ }^{\circledR}$ Cell Analysis System. Twenty-four hours after seeding, at $0 \mathrm{~h}$ time point, the indicated cell lines were treated with the FGFR inhibitor AZD4547 (A-D), and the PI3K inhibitors BEZ235 (E-H) and BYL719 (I-L). The experiments were performed up to $48 \mathrm{~h}$ after treatment. The graphs represent one out of three typical experiments.

Regarding the combination of AZD4547 and BYL719, 25 $\mu \mathrm{M}$ and $1.0 \mu \mathrm{M}$ of each drug, respectively inhibited proliferation in all the tested MB cell lines (DAOY: $p=0.03$, UW228-3: $p=0.003$, Med8a: $p=0.00003$, D425: $p=0.008$, all at $72 \mathrm{~h}$ ) (Figure 9E-H). For the $5 \mu \mathrm{M}$ AZD4547 and $0.25 \mu \mathrm{M}$ BYL719 concentrations, significant inhibition was observed in Med8a and D425, compared to PBS-treated controls ( $p=0.011$ and $p=0.01$ respectively, both at $72 \mathrm{~h}$ ) (Figure $9 \mathrm{G}$ and $\mathrm{H}$ ).

\section{Discussion}

In this study, FGFR and PI3K inhibitors were tested either alone or in combination for their ability to inhibit the growth of five MB cell lines. Of these, DAOY cell line had an inframe deletion in the PIK3Rl gene (https://depmap.org/portal/), while D425 and Med8a cell lines had Myc amplifications (6, 31, 32). All five MB cell lines were sensitive to the FGFR (AZD4547) and PI3K (BEZ235, BYL719) inhibitors alone, as shown by decreased viability and proliferation. However, only the FGFR inhibitor AZD4547 induced pronounced effects on cytotoxicity or apoptosis. The PI3K inhibitor BEZ235 was generally more efficient compared to BYL719, at the tested concentrations. Further testing of the combination of the drugs revealed increased inhibitory effects on cell viability, especially in the most resitant cell line UW228-3.

In the viability assays, D425 and D283 cell lines were sensitive to the FGFR inhibitor AZD4547, the UW228-3 cell line was the least sensitive, while DAOY and Med8a cells had intermediate sensitivity. DAOY and D425 cell lines were the most sensitive to the PI3K inhibitor BEZ235, while UW2283 cells was the least sensitive; Med8a and D283 cell lines had intermediate sensitivity. All cell lines showed decreased viability after treatment with the two highest concentrations of the PI3K inhibitor BYL719, except UW228-3 cell line that was only sensitive to the highest concentration.

Upon combination treatments with FGFR and PI3K inhibitors, an enhanced decrease in viability was observed in the least sensitive UW228-3 cell line, while all other MB cell lines retained the sensitivity they had to the drug they were most sensitive to. Again, at the concentrations used here, in 

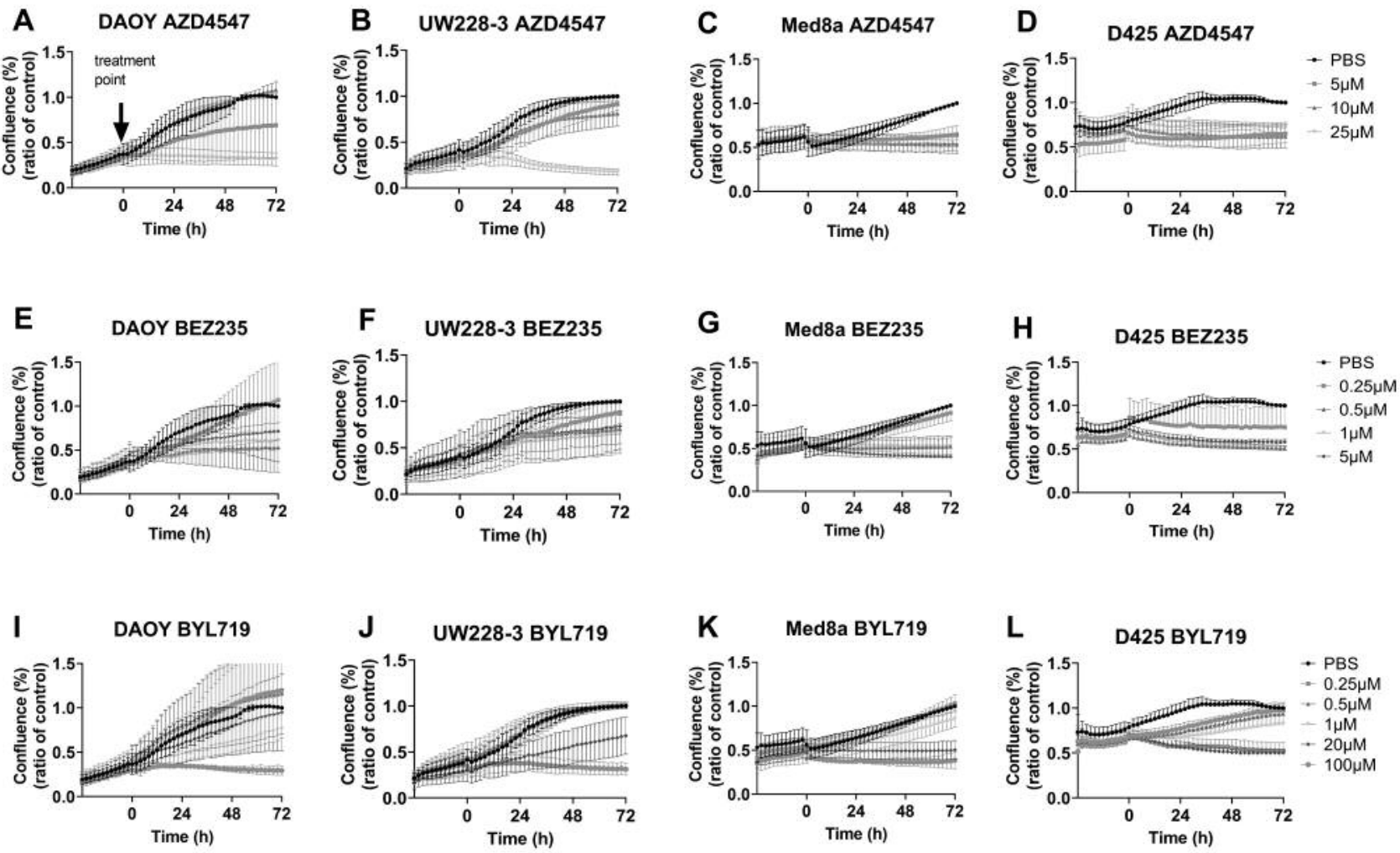

Figure 4. Proliferation assays after single treatments with FGFR and PI3K inhibitors on cell lines DAOY, UW228-3, Med8a, and D425. Proliferation assays were performed with the Incucyte 33 Live ${ }^{\circledR}$ Cell Analysis System. Twenty-four hours after seeding, at 0 h time point, the cells were treated with the FGFR inhibitor AZD4547 (A-D) and the PI3K inhibitors BEZ235 (F-H) and BYL719 (I-L) and the confluency was measured up to $72 \mathrm{~h}$ after treatment. The graphs represent the means with \pm standard deviation $(S D)$ of three experiments.

combination with the FGFR inhibitor AZD4547, the dual PI3K inhibitor, BEZ235, was more efficient than the $110 \alpha$ specific PI3K inhibitor, BYL719.

To our knowledge, sensitivity of MB cell lines to PI3K inhibitors has already been demonstrated before (35); however, this is the first study to examine sensitivity to FGFR inhibitors or to the combination of PI3K and FGFR inhibitors.

The marked sensitivity of DAOY to the PI3K inhibitor BEZ235 in the viability tests could be explained by the fact that DAOY cell line has an in-frame deletion in the PIK3RI gene. The overall sensitivity of the D425 and Med8a cell lines as well as of DAOY and D283, to both types of inhibitors, and especially to PI3K inhibitors is unknown. However, D425 and Med8a (Group 3) have Myc amplifications and D283 has overexpression of Myc $(6,31,32)$. PI3K/mTOR inhibitors have been shown to enhance Mycn phosphorylation and proteosomal degradation leading to high sensitivity to mTOR kinase inhibitors among cells with a Mycn amplification (36). Whether high expression of Myc in cells, similar to the presence of Mycn amplifications, increases their sensitivity to mTOR kinase inhibitors, should be further examined. Notably, it is known that Myc and Mycn have the same phosphorylation sites when tagged for ubiquitination and it has been shown that inhibition of mTOR-kinase destabilizes Mycn. Therefore, inhibition of mTOR-kinase may be a potential therapy for Mycn-dependent tumors (37). Nonetheless, development of resistance against targeted therapy has been reported when using one drug alone, and therefore the alternative of using two drugs in combination could be of benefit $(35,38,39)$.

Herein, in line with previous studies $(30,40)$, the FGFR inhibitor (AZD4547), but not the PI3K inhibitors, affected cytotoxicity and apoptosis. The fact that the FGFR inhibitors can induce cytotoxicity and apoptosis could be useful in clinical practice in $\mathrm{MB}$ patients; however, it is important to use as low drug concentrations as possible in order to avoid side effects of the various drugs (41).

Regarding the PI3K inhibitor BEZ235, the concentrations used on the MB cell lines have been previously used by us on neuroblastoma cell lines $(30,35)$; however, they were slightly higher than those used in a previous studies on MB cells $(30,35)$. The concentrations for the PI3K inhibitor BYL719 were similar to those used in a recent study in 

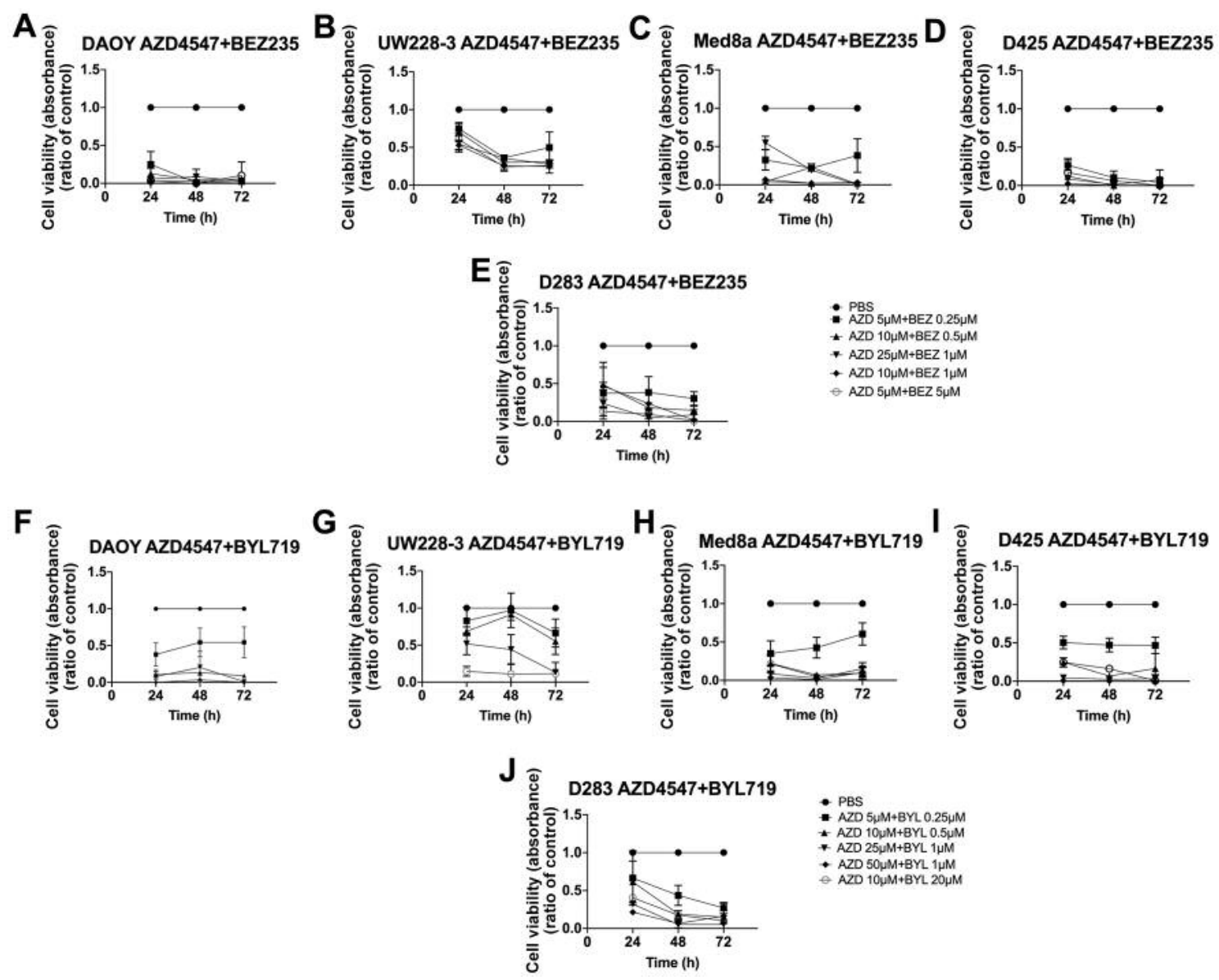

Figure 5. WST-1 viability assays after combined treatment with FGFR (AZD4547) and PI3K inhibitors (BEZ235; BYL719) on five MB cell lines. Combination treatments on the same cells indicated above of FGFR inhibitor AZD4547 and PI3K inhibitor BEZ235 are depicted in (A-E) and of FGFR inhibitor AZD4547 and PI3K inhibitor BYL719 in (F-J). The graphs represent mean values \pm standard deviation (SD) from three experimental runs per cell line.

neuroendocrine tumors (42), and the concentrations of the FGFR inhibitor AZD4547 have also been used in previous studies $(30,41)$. It is possible that cell lines with FGFR or PI3K mutations may be sensitive to lower drug concentrations, and such cell lines remain to be tested. Nevertheless, it has been reported that PI3K mutations do not always affect drug sensitivity (43). However, it has been documented that the sensitivity to FGFR inhibitors is affected in cervical tumors harboring FGFR3-TACC3-fusion genes as compared to those not harboring such genes (44).

There are limitations in this study, since only five MB cell lines were examined. Furthermore, a limited number of drug concentrations was used. Nevertheless, to our knowledge, this is the first time that drugs against FGFR and PI3K were used in combination for treatment of $\mathrm{MB}$ cell lines. Nevertheless, PI3K inhibitors have been previously shown to inhibit MB cell growth in vitro, as well as to suppress tumor growth in xenograft models when used alone or in combination with a hedgehog inhibitor $(28,35)$.

\section{Conclusion}

Treatment with FGFR or PI3K inhibitors induced a decrease in viability and proliferation in a dose-dependent manner in all the examined MB cell lines. On the other hand, the sensitivity of different MB cell lines to the tested inhibitors varied. The fact that high expression of FGFR3 in MB patients has been identified as a marker of treatment resistance makes FGFR inhibitors interesting candidates for combinational studies. Notably, however, upon combination treatment with FGFR and PI3K inhibitors the sensitivity of all cell lines increased, especially in the most resistant cell line. Taken together our data suggest that FGFR and PI3K inhibitor combination may be promising a treatment approach for resistant MBs. 

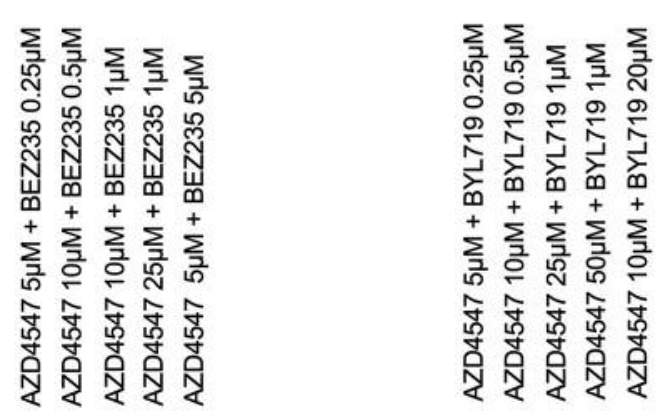

(1)

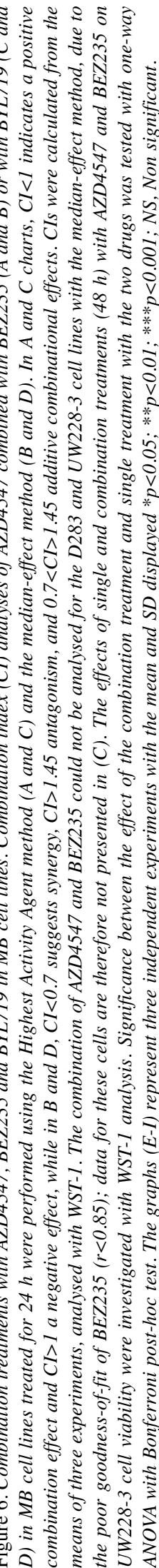

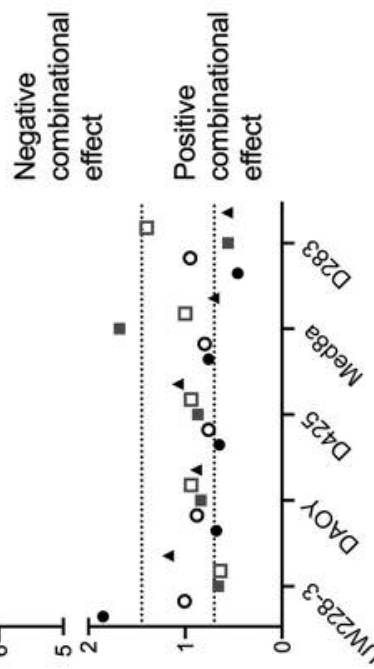

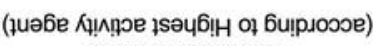
$<$ хәри! uoneulquo

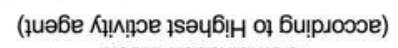

0

xәрu!̣ uo!̣eu!̣moว
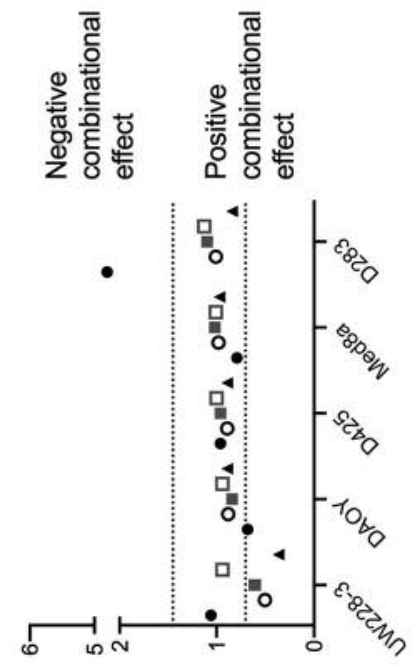

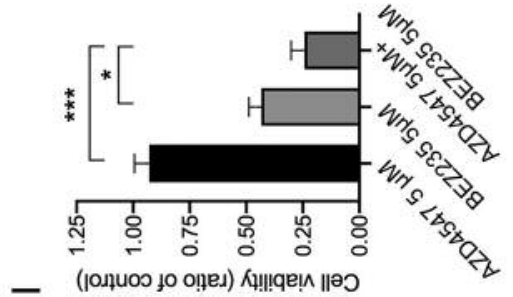

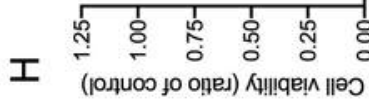

()

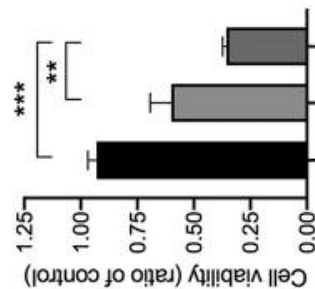

丩
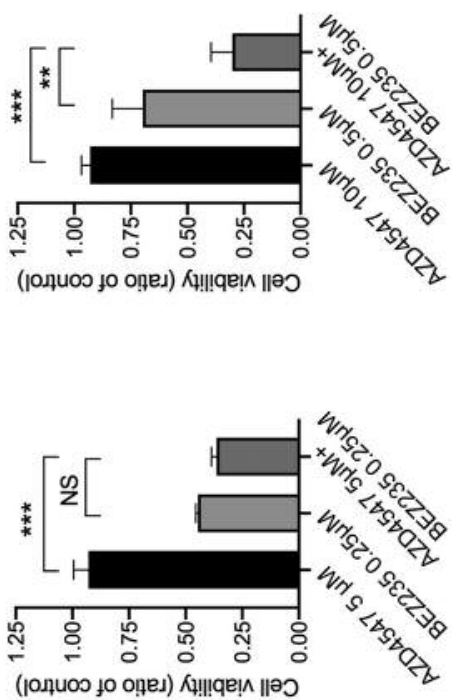

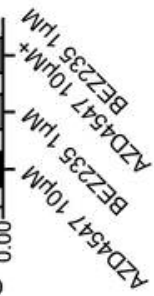

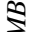

政

$\sqrt{20}$ ह 5

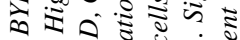

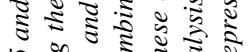
กิ

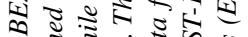

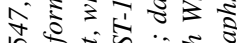
¿ गิ

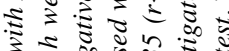

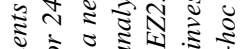
ปี ₹

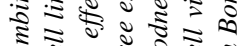
- 0.25 os

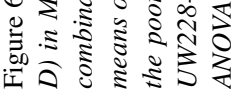



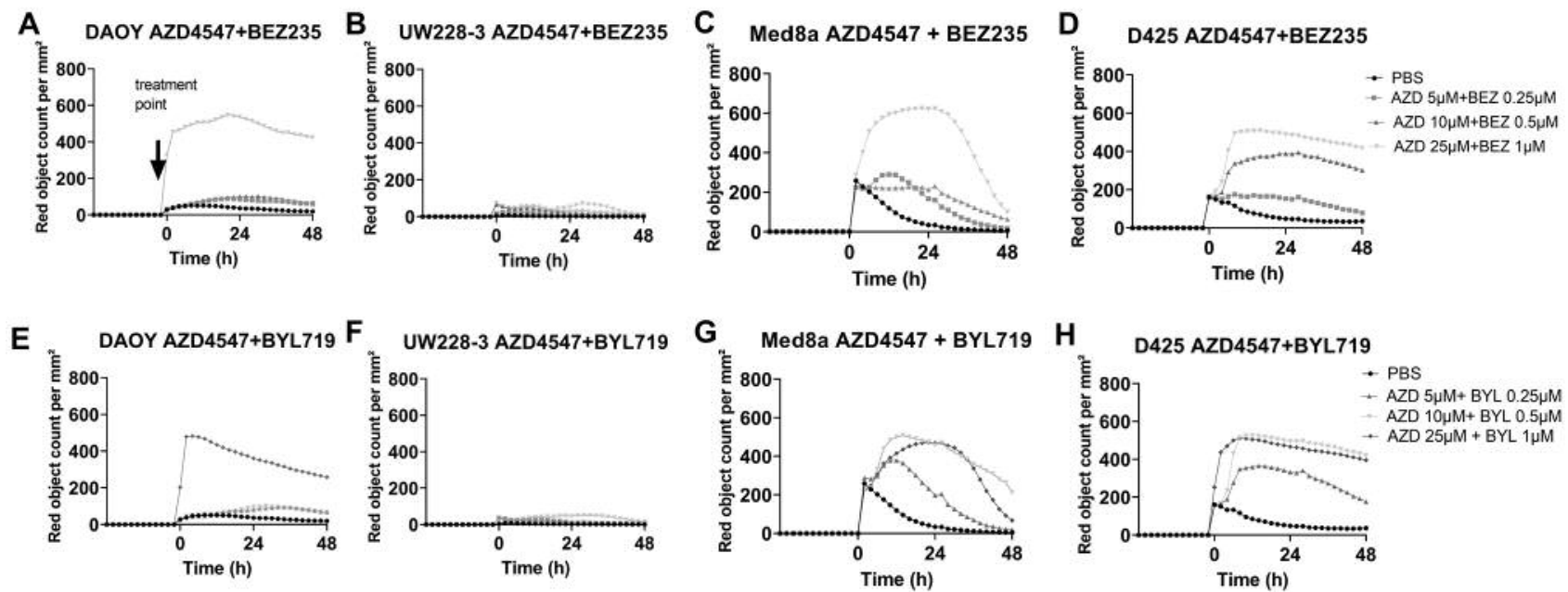

Figure 7. Cytotoxicity analysis after combination treatment with FGFR (AZD4547) and PI3K (BEZ235; BYL719) inhibitors using the IncuCyte Red Cytotoxicity Assay on the MB cell lines DAOY, UW228-3, Med8a, and D425. Twenty-four hours after seeding, at 0 h time point, the indicated cell lines were treated with drugs and the assays were performed up to $48 \mathrm{~h}$ after treatment. Combination treatments on the indicated cell lines with AZD4547 and BEZ235 are shown in (A-D) and of AZD4547 and BYL719 in (E-H). The graphs represent one out of three typical experiments.
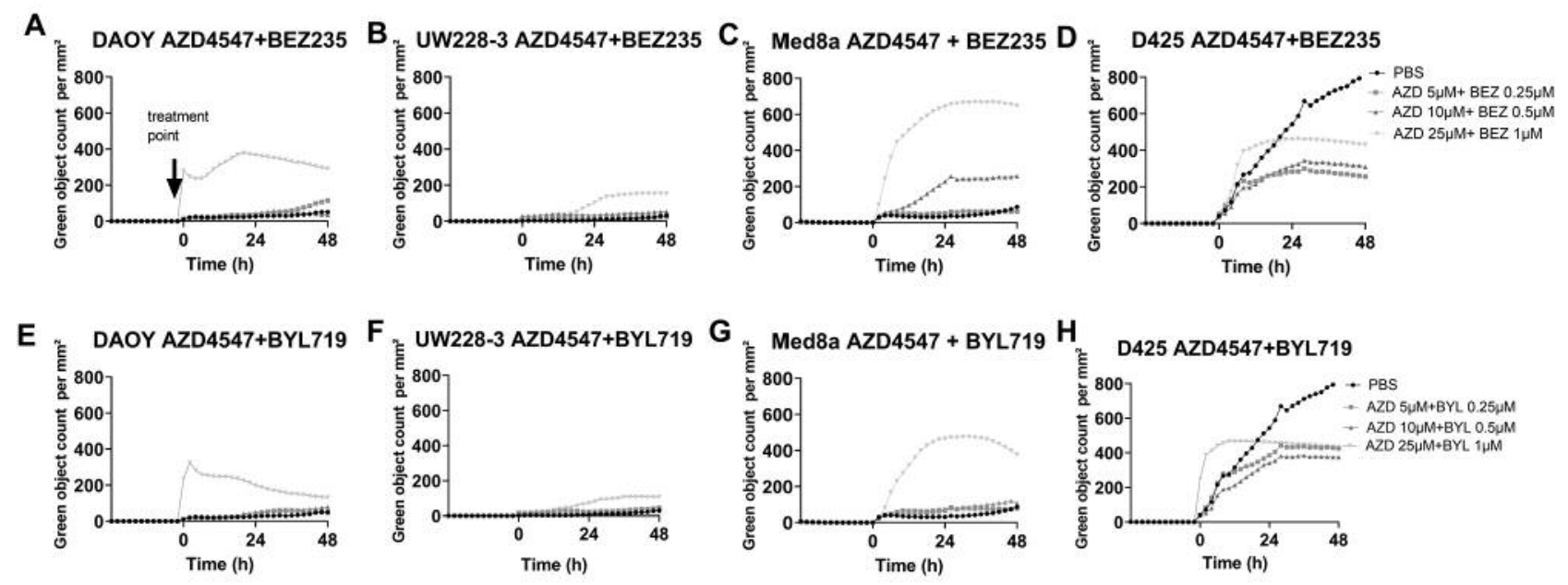

Figure 8. Caspase-3/7 Green apoptosis assay after combination treatment with FGFR (AZD4547) and PI3K (BEZ235; BYL719) on cell lines DAOY, UW228-3, Med8a, and D425 using the IncuCyte S3 Live ${ }^{\circledR}$ Cell Analysis System. Twenty-four h after seeding, at 0 hours time point, the indicated cell lines were treated with drugs and the assays were performed up to $48 \mathrm{~h}$ after treatment. Combination treatments on the indicated cell lines with AZD4547 and BEZ235 are depicted (A-D) as well as of AZD4547 and BYL719 (E-H). The graphs represent one out of three typical experiments.

\section{Conflicts of Interest}

The Authors declare that they have no conflicts of interest.

\section{Authors' Contributions}

$\mathrm{SH}$, performed the majority of the experiments and contributed to the writing of the manuscript. ML performed part of the experiments, and assisted in the data presentation, all under the supervision of ONK and $\mathrm{SH}$. TA performed experimental work and contributed to the writing of the manuscript. RGU performed the viability experiments. MW performed combinational analyses, and assisted in the final interpretation and presentation of the statistics of the manuscript and in the writing of the manuscript. TD, MW and ONK conceived and designed the study, made substantial contributions to the interpretation of the data, and were involved in the drafting of the manuscript and revising it critically for important intellectual content. All Authors have critically read and approved the manuscript. 

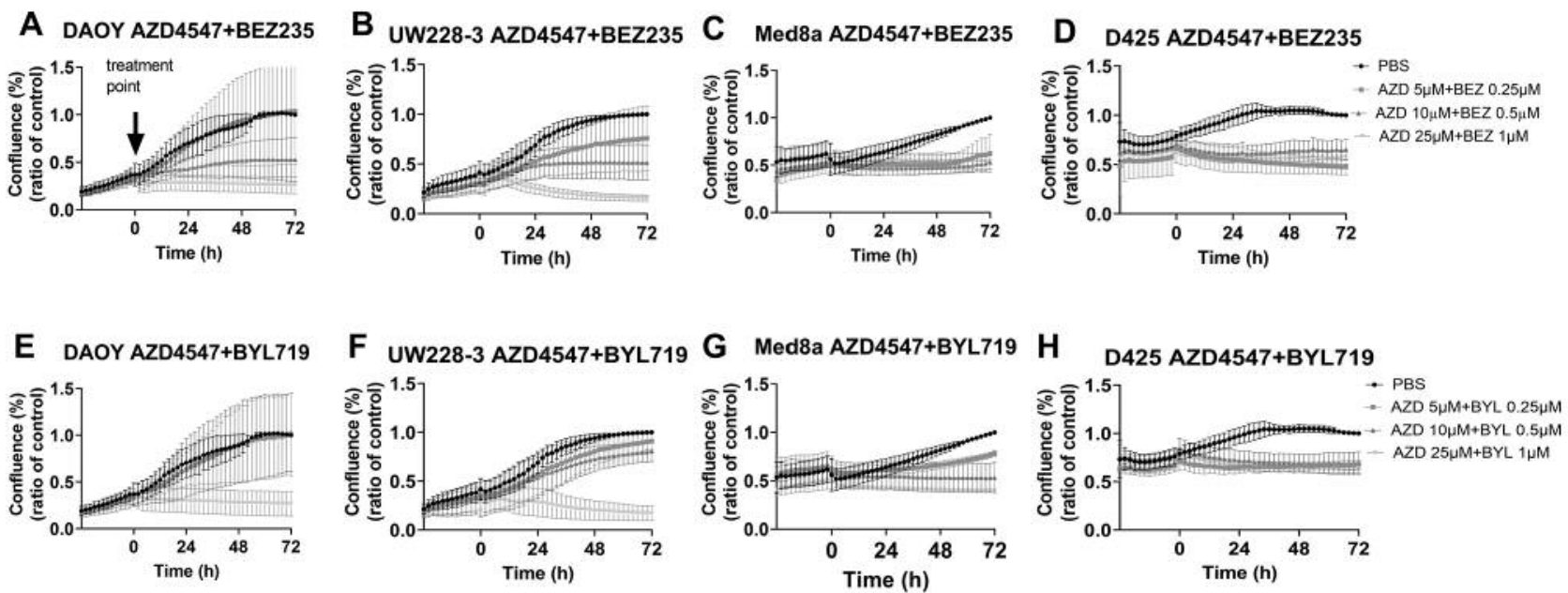

Figure 9. Proliferation assays after combination treatment with FGFR (AZD4547) and PI3K (BEZ235; BYL719) inhibitors on cell lines DAOY, UW228-3, Med8a, and D425. Proliferation assays were performed with the Incucyte S3 Live ${ }^{\circledR}$ Cell Analysis System. Twenty-four hours after seeding, the cells were treated with a combination of FGFR inhibitor AZD4547 and the PI3K inhibitors BEZ235 or BYL719. Combination treatments with AZD4547 and BEZ235 are shown in (A-D) and with AZD4547 with BYL719 in (E-H). The graphs represent the means with \pm standard deviation (SD) of three experiments.

\section{Acknowledgements}

This research was supported by the The Swedish Childhood Cancer Fund, the Swedish Cancer Society, the Stockholm Cancer Society, the Swedish Cancer and Allergy Foundation, the Stockholm City Council, the Karolinska Institutet of Sweden, Lindhés Advokatbyrå. RGU was funded by the University of Medicine and Pharmacy, Grigore T Popa, Iasi, Romania (grant no. 30336/28.12.2017).

\section{References}

1 Steliarova-Foucher E, Colombet M, Ries LAG, Moreno F, Dolya A, Bray F, Hesseling P, Shin HY, Stiller CA and IICC-3 contributors: International incidence of childhood cancer, 2001-10: A population-based registry study. Lancet Oncol 18(6): 719-731, 2017. PMID: 28410997. DOI: 10.1016/s1470-2045(17)30186-9

2 Ward E, DeSantis C, Robbins A, Kohler B and Jemal A: Childhood and adolescent cancer statistics, 2014. CA Cancer J Clin 64(2): 83103, 2014. PMID: 24488779. DOI: 10.3322/caac.21219

3 Massimino M, Giangaspero F, Garre ML, Gandola L, Poggi G, Biassoni V, Gatta G and Rutkowski S: Childhood medulloblastoma. Crit Rev Oncol Hematol 79(1): 65-83, 2011. PMID: 21129995. DOI: $10.1016 /$ j.critrevonc.2010.07.010

4 Grimmer MR and Weiss WA: Childhood tumors of the nervous system as disorders of normal development. Curr Opin Pediatr 18(6): 634-638, 2006. PMID: 17099362. DOI: 10.1097/MOP. 0b013e32801080fe

5 Scotting PJ, Walker DA and Perilongo G: Childhood solid tumours: A developmental disorder. Nat Rev Cancer 5(6): 481488, 2005. PMID: 15905853. DOI: $10.1038 / \mathrm{nrc} 1633$

6 Ivanov DP, Coyle B, Walker DA and Grabowska AM: In vitro models of medulloblastoma: Choosing the right tool for the job. J Biotechnol 236: 10-25, 2016. PMID: 27498314. DOI: 10.1016/j.jbiotec.2016.07.028
7 Northcott PA, Jones DT, Kool M, Robinson GW, Gilbertson RJ, Cho YJ, Pomeroy SL, Korshunov A, Lichter P, Taylor MD and Pfister SM: Medulloblastomics: The end of the beginning. Nat Rev Cancer 12(12): 818-834, 2012. PMID: 23175120. DOI: $10.1038 / \mathrm{nrc} 3410$

8 Kool M, Korshunov A, Remke M, Jones DT, Schlanstein M, Northcott PA, Cho YJ, Koster J, Schouten-van Meeteren A, van Vuurden D, Clifford SC, Pietsch T, von Bueren AO, Rutkowski S, McCabe M, Collins VP, Backlund ML, Haberler C, Bourdeaut F, Delattre O, Doz F, Ellison DW, Gilbertson RJ, Pomeroy SL, Taylor MD, Lichter P and Pfister SM: Molecular subgroups of medulloblastoma: An international meta-analysis of transcriptome, genetic aberrations, and clinical data of WNT, SHH, Group 3, and Group 4 medulloblastomas. Acta Neuropathol 123(4): 473-484, 2012. PMID: 22358457. DOI: 10.1007/s00401-012-0958-8

9 Cho YJ, Tsherniak A, Tamayo P, Santagata S, Ligon A, Greulich H, Berhoukim R, Amani V, Goumnerova L, Eberhart CG, Lau CC, Olson JM, Gilbertson RJ, Gajjar A, Delattre O, Kool M, Ligon K, Meyerson M, Mesirov JP and Pomeroy SL: Integrative genomic analysis of medulloblastoma identifies a molecular subgroup that drives poor clinical outcome. J Clin Oncol 29(11): 1424-1430, 2011. PMID: 21098324. DOI: $10.1200 / J C O .2010 .28 .5148$

10 Gibson P, Tong Y, Robinson G, Thompson MC, Currle DS, Eden C, Kranenburg TA, Hogg T, Poppleton H, Martin J, Finkelstein D, Pounds S, Weiss A, Patay Z, Scoggins M, Ogg R, Pei Y, Yang ZJ, Brun S, Lee Y, Zindy F, Lindsey JC, Taketo MM, Boop FA, Sanford RA, Gajjar A, Clifford SC, Roussel MF, McKinnon PJ, Gutmann DH, Ellison DW, Wechsler-Reya R and Gilbertson RJ: Subtypes of medulloblastoma have distinct developmental origins. Nature 468(7327): 1095-1099, 2010. PMID: 21150899. DOI: $10.1038 /$ nature09587

11 Taylor MD, Northcott PA, Korshunov A, Remke M, Cho YJ, Clifford SC, Eberhart CG, Parsons DW, Rutkowski S, Gajjar A, Ellison DW, Lichter P, Gilbertson RJ, Pomeroy SL, Kool M and Pfister SM: Molecular subgroups of medulloblastoma: The 
current consensus. Acta Neuropathol 123(4): 465-472, 2012. PMID: 22134537. DOI: 10.1007/s00401-011-0922-z

12 Millard NE and De Braganca KC: Medulloblastoma. J Child Neurol 31(12): 1341-1353, 2016. PMID: 26336203. DOI: 10.1177/0883073815600866

13 Dimitrova V and Arcaro A: Targeting the PI3K/AKT/mTOR signaling pathway in medulloblastoma. Curr Mol Med 15(1): 8293, 2015. PMID: 25601471. DOI: 10.2174/1566524015 666150114115427

14 Dai S, Zhou Z, Chen Z, Xu G and Chen Y: Fibroblast growth factor receptors (FGFRs): Structures and small molecule inhibitors. Cells 8(6): E614, 2019. PMID: 31216761. DOI: $10.3390 /$ cells 8060614

15 Bourdeaut F, Miquel C, Di Rocco F, Grison C, Richer W, Brugieres L, Pierron G, James S, Baujat G, Delattre O and Collet C: Germline mutations in FGF receptors and medulloblastomas. Am J Med Genet A 161A(2): 382-385, 2013. PMID: 23325524. DOI: 10.1002/ajmg.a.35719

16 Pomeroy SL, Tamayo P, Gaasenbeek M, Sturla LM, Angelo M, McLaughlin ME, Kim JYH, Goumnerova LC, Black PM, Lau C, Allen JC, Zagzag D, Olson JM, Curran T, Wetmore C, Biegel JA, Poggio T, Mukherjee S, Rifkin R, Califano A, Stolovitzky G, Louis DN, Mesirov JP, Lander ES and Golub TR: Prediction of central nervous system embryonal tumour outcome based on gene expression. Nature 415(6870): 436-442, 2002. PMID: 11807556. DOI: $10.1038 / 415436$ a

17 Lehtinen B, Raita A, Kesseli J, Annala M, Nordfors K, Yli-Harja O, Zhang W, Visakorpi T, Nykter M, Haapasalo H and Granberg $\mathrm{KJ}$ : Clinical association analysis of ependymomas and pilocytic astrocytomas reveals elevated FGFR3 and FGFR1 expression in aggressive ependymomas. BMC Cancer 17(1): 310, 2017. PMID: 28468611. DOI: 10.1186/s12885-017-3274-9

18 Yuan TL and Cantley LC: PI3K pathway alterations in cancer: Variations on a theme. Oncogene 27(41): 5497-5510, 2008. PMID: 18794884. DOI: 10.1038/onc.2008.245

19 Samuels Y and Waldman T: Oncogenic mutations of PIK3CA in human cancers. Curr Top Microbiol Immunol 347: 21-41, 2010. PMID: 20535651. DOI: 10.1007/82_2010_68

20 Janku F: Phosphoinositide 3-kinase (PI3K) pathway inhibitors in solid tumors: From laboratory to patients. Cancer Treat Rev 59. 93-101, 2017. PMID: 28779636. DOI: 10.1016/j.ctrv.2017.07.005

21 Robinson G, Parker M, Kranenburg TA, Lu C, Chen X, Ding L, Phoenix TN, Hedlund E, Wei L, Zhu X, Chalhoub N, Baker SJ, Huether R, Kriwacki R, Curley N, Thiruvenkatam R, Wang J, Wu G, Rusch M, Hong X, Becksfort J, Gupta P, Ma J, Easton J, Vadodaria B, Onar-Thomas A, Lin T, Li S, Pounds S, Paugh S, Zhao D, Kawauchi D, Roussel MF, Finkelstein D, Ellison DW, Lau CC, Bouffet E, Hassall T, Gururangan S, Cohn R, Fulton RS, Fulton LL, Dooling DJ, Ochoa K, Gajjar A, Mardis ER, Wilson RK, Downing JR, Zhang J and Gilbertson RJ: Novel mutations target distinct subgroups of medulloblastoma. Nature 488(7409): 43-48, 2012. PMID: 22722829. DOI: 10.1038/nature11213

22 Kandula M, Chennaboina KK, Ys AR and Raju S: Phosphatidylinositol 3-kinase (PI3KCA) oncogene mutation analysis and gene expression profiling in primary breast cancer patients. Asian Pac J Cancer Prev 14(9): 5067-5072, 2013. PMID: 24175777. DOI: 10.7314/apjcp.2013.14.9.5067

23 Rosty C, Young JP, Walsh MD, Clendenning M, Sanderson K, Walters RJ, Parry S, Jenkins MA, Win AK, Southey MC, Hopper JL, Giles GG, Williamson EJ, English DR and Buchanan DD:
PIK3CA activating mutation in colorectal carcinoma: Associations with molecular features and survival. PLoS One 8(6): e65479, 2013. PMID: 23785428. DOI: 10.1371/journal.pone.0065479

24 Ogino S, Liao X, Imamura Y, Yamauchi M, McCleary NJ, Ng K, Niedzwiecki D, Saltz LB, Mayer RJ, Whittom R, Hantel A, Benson AB, 3rd, Mowat RB, Spiegelman D, Goldberg RM, Bertagnolli MM, Meyerhardt JA, Fuchs CS and Alliance for Clinical Trials in O: Predictive and prognostic analysis of PIK3CA mutation in stage III colon cancer intergroup trial. J Natl Cancer Inst 105(23): 1789-1798, 2013. PMID: 24231454. DOI: $10.1093 /$ jnci/djt298

25 Shukla N, Ameur N, Yilmaz I, Nafa K, Lau CY, Marchetti A, Borsu L, Barr FG and Ladanyi M: Oncogene mutation profiling of pediatric solid tumors reveals significant subsets of embryonal rhabdomyosarcoma and neuroblastoma with mutated genes in growth signaling pathways. Clin Cancer Res 18(3): 748-757, 2012. PMID: 22142829. DOI: 10.1158/1078-0432.CCR-11-2056

26 Day FL, Jorissen RN, Lipton L, Mouradov D, Sakthianandeswaren A, Christie M, Li S, Tsui C, Tie J, Desai J, Xu ZZ, Molloy P, Whitehall V, Leggett BA, Jones IT, McLaughlin S, Ward RL, Hawkins NJ, Ruszkiewicz AR, Moore J, Busam D, Zhao Q, Strausberg RL, Gibbs P and Sieber OM: PIK3CA and PTEN gene and exon mutation-specific clinicopathologic and molecular associations in colorectal cancer. Clin Cancer Res 19(12): 32853296, 2013. PMID: 23633456. DOI: 10.1158/1078-0432.CCR-123614

27 Ollikainen M, Gylling A, Puputti M, Nupponen NN, AbdelRahman WM, Butzow R and Peltomaki P: Patterns of PIK3CA alterations in familial colorectal and endometrial carcinoma. Int J Cancer 121(4): 915-920, 2007. PMID: 17471559. DOI: $10.1002 /$ ijc. 22768

28 Zhao P, Hall J, Durston M, Voydanoff A, VanSickle E, Kelly S, Nagulapally AB, Bond J and Saulnier Sholler G: BKM120 induces apoptosis and inhibits tumor growth in medulloblastoma. PLoS One 12(6): e0179948, 2017. PMID: 28662162. DOI: 10.1371/journal.pone. 0179948

29 Chaturvedi NK, McGuire TR, Coulter DW, Shukla A, McIntyre EM, Sharp JG and Joshi SS: Improved therapy for neuroblastoma using a combination approach: Superior efficacy with vismodegib and topotecan. Oncotarget 7(12): 15215-15229, 2016. PMID: 26934655. DOI: 10.18632/oncotarget.7714

30 Kostopoulou ON, Holzhauser S, Lange BKA, Ohmayer A, Andonova T, Bersani C, Wickstrom M and Dalianis T: Analyses of FGFR3 and PIK3CA mutations in neuroblastomas and the effects of the corresponding inhibitors on neuroblastoma cell lines. Int J Oncol 55(6): 1372-1384, 2019. PMID: 31638167. DOI: $10.3892 /$ ijo.2019.4896

31 Langdon JA, Lamont JM, Scott DK, Dyer S, Prebble E, Bown $\mathrm{N}$, Grundy RG, Ellison DW and Clifford SC: Combined genome-wide allelotyping and copy number analysis identify frequent genetic losses without copy number reduction in medulloblastoma. Genes Chromosomes Cancer 45(1): 47-60, 2006. PMID: 16149064. DOI: 10.1002/gcc.20262

32 Bigner SH, Friedman HS, Vogelstein B, Oakes WJ and Bigner DD: Amplification of the c-myc gene in human medulloblastoma cell lines and xenografts. Cancer Res 50(8): 2347-2350, 1990. PMID: 2180567.

33 Foucquier $\mathbf{J}$ and Guedj M: Analysis of drug combinations: Current methodological landscape. Pharmacol Res Perspect 3(3): e00149, 2015. PMID: 26171228. DOI: 10.1002/prp2.149 
34 Chou TC: Drug combination studies and their synergy quantification using the Chou-Talalay method. Cancer Res 70(2): 440-446, 2010. PMID: 20068163. DOI: 10.1158/00085472.CAN-09-1947

35 Chaturvedi NK, Kling MJ, Coulter DW, McGuire TR, Ray S, Kesherwani V, Joshi SS and Sharp JG: Improved therapy for medulloblastoma: Targeting hedgehog and PI3K-mTOR signaling pathways in combination with chemotherapy. Oncotarget 9(24): 16619-16633, 2018. PMID: 29682173. DOI: 10.18632/oncotarget. 24618

36 Vaughan L, Clarke PA, Barker K, Chanthery Y, Gustafson CW, Tucker E, Renshaw J, Raynaud F, Li X, Burke R, Jamin Y, Robinson SP, Pearson A, Maira M, Weiss WA, Workman P and Chesler L: Inhibition of mTOR-kinase destabilizes MYCN and is a potential therapy for MYCN-dependent tumors. Oncotarget 7(36): 57525-57544, 2016. PMID: 27438153. DOI: 10.18632 /oncotarget.10544

37 Gustafson WC and Weiss WA: Myc proteins as therapeutic targets. Oncogene 29(9): 1249-1259, 2010. PMID: 20101214. DOI: $10.1038 /$ onc.2009.512

38 Cai W, Song B and Ai H: Combined inhibition of FGFR and mTOR pathways is effective in suppressing ovarian cancer. Am J Transl Res 11(3): 1616-1625, 2019. PMID: 30972187.

39 Hsu CM, Lin PM, Lin HC, Tsai YT, Tsai MS, Li SH, Wu CY, Yang YH, Lin SF and Yang MY: NVP-BEZ235 attenuated cell proliferation and migration in the squamous cell carcinoma of oral cavities and p70S6K inhibition mimics its effect. Int J Mol Sci 19(11): E3546, 2018. PMID: 30423811. DOI: 10.3390/ ijms19113546

40 Segerström L, Baryawno N, Sveinbjörnsson B, Wickström M, Elfman L, Kogner P and Johnsen JI: Effects of small molecule inhibitors of $\mathrm{PI} 3 \mathrm{~K} / \mathrm{Akt} / \mathrm{mTOR}$ signaling on neuroblastoma growth in vitro and in vivo. Int J Cancer 129(12): 2958-2965, 2011. PMID: 21717457. DOI: $10.1002 / \mathrm{ijc} .26268$
41 Brands RC, Knierim LM, De Donno F, Steinacker V, Hartmann S, Seher A, Kubler AC and Muller-Richter UDA: Targeting VEGFR and FGFR in head and neck squamous cell carcinoma in vitro. Oncol Rep 38(3): 1877-1885, 2017. PMID: 28714017. DOI: 10.3892/or.2017.5801

42 Nolting S, Rentsch J, Freitag H, Detjen K, Briest F, Mobs M, Weissmann V, Siegmund B, Auernhammer CJ, Aristizabal Prada ET, Lauseker M, Grossman A, Exner S, Fischer C, Grotzinger C, Schrader J, Grabowski P and group GN-Zs: The selective PI3K $\alpha$ inhibitor BYL719 as a novel therapeutic option for neuroendocrine tumors: Results from multiple cell line models. PLoS One 12(8): e0182852, 2017. PMID: 28800359. DOI: 10.1371/journal.pone.0182852

43 Munster P, Aggarwal R, Hong D, Schellens JH, van der Noll R, Specht J, Witteveen PO, Werner TL, Dees EC, Bergsland E, Agarwal N, Kleha JF, Durante M, Adams L, Smith DA, Lampkin TA, Morris SR and Kurzrock R: First-in-human phase I study of GSK2126458, an oral pan-class I phosphatidylinositol-3-kinase inhibitor, in patients with advanced solid tumor malignancies. Clin Cancer Res 22(8): 1932-1939, 2016. PMID: 26607258. DOI: 10.1158/1078-0432.CCR-15-1665

44 Tamura R, Yoshihara K, Saito T, Ishimura R, Martinez-Ledesma JE, Xin H, Ishiguro T, Mori Y, Yamawaki K, Suda K, Sato S, Itamochi H, Motoyama T, Aoki Y, Okuda S, Casingal CR, Nakaoka H, Inoue I, Verhaak RGW, Komatsu M and Enomoto T: Novel therapeutic strategy for cervical cancer harboring FGFR3-TACC3 fusions. Oncogenesis 7(1): 4, 2018. PMID: 29358619. DOI: $10.1038 / \mathrm{s} 41389-017-0018-2$

Received October 31, 2019

Revised November 29, 2019 Accepted December 12, 2019 